\title{
Avomaankurkkua kausihuoneesta ja avomaalta
}

\author{
Anu Räty ${ }^{1)}$, Vesa Järvelin ${ }^{1)}$, Janne Ylijoki ${ }^{1)}$, Hanna Kekkonen ${ }^{2)}$, Kaisa Soppela ${ }^{3)}$ \\ ${ }^{1)}$ MTT Sotkamo, Kipinäntie 16, 88600 Sotkamo, etunimi.sukunimi@mtt.fi \\ ${ }^{2)}$ MTT Ruukki, Tutkimusasemantie 15,92400 Ruukki, etunimi.sukunimi@mtt.fi \\ ${ }^{3)}$ MTT Rovaniemi, Eteläranta 55, 96300 Rovaniemi, etunimi.sukunimi@mtt.fi
}

\section{Tiivistelmä}

MTT Sotkamossa, Ruukissa ja Rovaniemellä verrattiin avomaankurkun kasvatusta kausihuoneessa ja avomaalla kasvukausina 2012-2013. Kokeet tehtiin osana EU:n maaseuturahaston rahoittamaan Vihannesviljelystä vahva elinkeino Pohjois-Suomeen - hanketta.

Kokeessa käytettiin kahta partenokarppista lajiketta, Corentine ja Monolit. Kevään koleuden ja märkyyden takia taimia päästiin istuttamaan vasta kesäkuussa puolen välin tienoilla. Avomaalle taimet istutettiin kesäkuun loppupuolella. Kurkut istutettiin sekä kausihuoneessa että avomaalla mustalla kurkkukalvolla katettuihin mataliin penkkeihin. Kastelut ja lisälannoitus annettiin penkkeihin sijoitettujen tihkuletkujen kautta. Kausihuoneessa taimet tuettiin naruilla pystyasentoon. Avomaalla taimet saivat kasvaa vapaasti.

Avomaankurkun satokausi alkoi 2012 kaikilla kolmella tutkimuspaikkakunnalla lähes samaan aikaan. Ensimmäinen sato korjattiin kausihuoneesta heinäkuun puolen välin jälkeen ja avomaalta elokuun alussa. Kausihuoneessa satokausi alkoi noin kaksi viikkoa aikaisemmin kuin avomaalla. Rovaniemellä kausihuoneen ensimmäistä satoa päästiin keräämään neljän viikon päästä istutuksesta, kun Sotkamossa ja Ruukissa tähän meni reilu viisi viikkoa. Molempina tutkimusvuosina parhaan satokauden aikaan satoa korjattiin 2-3 päivän välein. Satokausi jatkui syyskuun puolelle.

Sotkamossa ja Ruukissa kausihuoneen kurkkusato oli 2012 yli kolminkertainen avomaan satoon verrattuna. Rovaniemellä päästiin kausihuoneessa lähes kaksi kertaa suurempaan satoon kuin avomaalla. Sekä kausihuoneessa että avomaalla sadon laatu oli erinomainen, huonoja kurkkuja esiintyi vasta satokauden loppupuolella. Kaudella 2013 satoerot tasoittuivat.

Luultavasti yksi syy vuoden 2012 suuriin satoeroihin kausihuoneen ja avomaan välillä löytyy kasvukauden säistä. Kolea sää suosi kausihuoneessa kasvatusta. Kausihuoneen tuuletuksesta ja kurkun versojen karsimisesta huolimatta esiintyi kausihuoneen kurkun versoissa loppukesällä pahkahometta. Sen sijaan avomaakasvustot säästyivät pahkahomeelta.

\section{Asiasanat}

Avomaankurkku, kausihuone, avomaa 


\section{Johdanto}

Pohjois-Suomessa kasvukauden lyhyys ja alhaiset lämpötilat rajoittavat vihannesviljelyä ja vähentävät viljelyn kannattavuutta. MTT Sotkamossa, Ruukissa ja Rovaniemellä selvitettiin kausihuoneen hyödyntämismahdollisuutta avomaankurkun kasvatuksessa. Tutkimuksessa verrattiin avomaankurkun kasvatusta kausihuoneessa ja avomaalla. Kokeessa haluttiin selvittää saadaanko pohjoisessa kausihuoneella aikaistettua avomaankurkun ensimmäistä sadonkorjuuajankohtaa ja kohotettua satotasoa avomaakasvatukseen verrattuna.

Kokeet tehtiin osana EU:n maaseuturahaston rahoittamaan Vihannesviljelystä vahva elinkeino Pohjois-Suomeen - hanketta, jota rahoittaa EU:n maaseuturahasto Kainuun, Pohjois-Pohjanmaan ja Lapin ELY-keskusten kautta.

\section{Aineisto ja menetelmät}

Kokeessa käytettiin kahta partenokarppista avomaankurkkulajiketta, Corentine ja Monolit. Lajikkeita kokeisiin toimittivat siemenliikkeet S.G. Nieminen ja Helle Oy. Kausihuonetaimien esikasvatus aloitettiin toukokuun lopussa ja avomaataimien kesäkuun alussa. Taimien esikasvatus tehtiin keskitetysti MTT Ruukissa. Kevään 2012 koleuden ja märkyyden takia taimia päästiin istuttamaan vasta kesäkuussa puolen välin tienoilla. Keväällä 2013 olosuhteet olivat paremmat ja istuttamaan päästiin noin viikkoa aikaisemmin (taulukko 1).

Kausihuoneessa taimia istutettiin neljä kappaletta neliölle ja avomaalle kuusi tainta neliölle. Kurkut istutettiin sekä kausihuoneessa että avomaalla mustalla kurkkukalvolla katettuihin mataliin penkkeihin. Kastelut ja lisälannoitus suoritettiin penkkeihin sijoitettujen tihkuletkujen kautta. Kausihuoneessa taimet tuettiin naruilla kasvamaan pystyasentoon. Avomaalla taimet saivat kasvaa vapaasti. Keväällä hallan uhatessa kasvustot peitettiin harsolla. Koejärjestelyt ja hoitotoimet olivat samat kaikilla tutkimuspaikkakunnilla (Sotkamossa, Ruukissa ja Rovaniemellä).

\section{Tulokset ja niiden tarkastelu}

Avomaankurkun satokausi 2012 alkoi kaikilla kolmella tutkimuspaikkakunnalla lähes samaan aikaan (taulukko 1). Kausihuoneen ensimmäinen sato kerättiin molempina vuosina heinäkuun puolessa välissä. Kesällä 2013 poikkeuksena oli Ruukki, jossa satoa päästiin keräämään kausihuoneesta jo viikkoa aikaisemmin kuin muilla tutkimuspaikkakunnilla. Mutta myös istutus tapahtui Ruukissa kaksi viikko aikaisemmin kuin Sotkamossa ja Rovaniemellä. Avomaalla satoa päästiin 2013 korjaamaan heinäkuun lopulla, noin viikkoa aikaisemmin kuin kasvukaudella 2012.

Taulukko 1: Avomaankurkun istutus, ensimmäinen sato ja sadonkorjuun lopetus päivät kasvukausina 2012-2013

\begin{tabular}{|l|l|l|l|l|l|l|l|l|l|l|l|l|l|l|}
\hline & \multicolumn{4}{l|}{ Taimien istutus pvm } & \multicolumn{3}{l|}{ Ensimmäinen sato pvm } & \multicolumn{3}{l|}{ Sadonkorjuun lopetus pvm } \\
\hline & Kausihuone & \multicolumn{2}{l|}{ Avomaa } & \multicolumn{2}{l|}{ Kausihuone } & \multicolumn{2}{l|}{ Avomaa } & \multicolumn{2}{l|}{ Kausihuone } & \multicolumn{2}{l|}{ Avomaa } \\
\hline & 2012 & 2013 & 2012 & 2013 & 2012 & 2013 & 2012 & 2013 & 2012 & 2013 & 2012 & 2013 \\
\hline Sotkamo & 12.6 & 18.6 & 25.6 & 18.6 & 18.7 & 16.7 & 1.8 & 25.7 & 20.9 & 16.9 & 14.9 & 16.9 \\
\hline Ruukki & 11.6 & 4.6 & 18.6 & 13.6 & 16.7 & 9.7 & 3.8 & 22.7 & 4.9 & 30.9 & 4.9 & 25.9 \\
\hline Rovaniemi & 21.6 & 17.6 & 28.6 & 20.6 & 17.7 & 15.7 & 1.8 & 26.7 & 11.9 & 9.9 & 14.9 & 24.9 \\
\hline
\end{tabular}

Taulukko 2. Avomaankurkun ensimmäinen sato istutuksesta viikkoina

\begin{tabular}{|l|l|l|l|l|}
\hline \multicolumn{2}{|l|}{ Kausihuone } & Avomaa \\
\hline & 2012 & 2013 & 2012 & 2013 \\
\hline Sotkamo & 5,3 & 4,1 & 5,4 & 5,4 \\
\hline Ruukki & 5,1 & 5,1 & 6,7 & 5,7 \\
\hline Rovaniemi & 3,9 & 4,1 & 5,0 & 5,3 \\
\hline
\end{tabular}


Kesällä 2012 kausihuoneessa satokausi alkoi reilu kaksi viikkoa aikaisemmin kuin avomaalla. Kasvukaudella 2013 kausihuoneen satoa aikaistava vaikutus avomaahan verrattuna lyheni 4 - 5 päivällä vuodesta 2012.

Kaudella 2012 Rovaniemellä kausihuoneen ensimmäistä satoa päästiin keräämään neljän viikon päästä istutuksesta, kun Sotkamossa ja Ruukissa tähän meni reilu viisi viikkoa (taulukko 2). Sotkamossa ja Rovaniemellä 2013 saatiin ensimmäinen sato neljä viikkoa istutuksesta. Ruukin ensimmäinen sato kerättiin viiden viikon kuluttua istutuksesta. Ruukissa kausihuonekurkut istutettiin kaksi viikkoa aikaisemmin kuin Sotkamossa ja Rovaniemellä. Parhaana satokautena satoa korjattiin 2-3 päivän välein. Satokausi jatkui kausihuoneessa ja avomaalla sekä kaikilla tutkimuspaikkakunnilla molempina vuosina syyskuun puolelle.

Sotkamossa ja Ruukissa kausihuoneen kurkkusato oli 2012 yli kolminkertainen avomaan satoon verrattuna. Rovaniemellä päästiin kausihuoneessa lähes kaksi kertaa suurempaan satoon kuin avomaalla (kuva 1). Kaudella 2013 Ruukissa ja Rovaniemellä kausihuoneen kurkkusato kasvoi vuodesta 2012. Sen sijaan Sotkamossa kausihuoneensato pieneni. Avomaan sadot hieman kasvoivat Ruukissa ja Rovaniemellä. Lajikkeiden välillä ei esiintynyt suuria satoeroja.

Kaudella 2012 sekä kausihuoneessa että avomaalla sadon laatu oli erinomainen, huonoja kurkkuja esiintyi vasta satokauden loppupuolella. Kesällä 2013 huonoja esiintyi enemmän.

Kausihuoneen tuuletuksesta ja kurkun versojen karsimisesta huolimatta loppukesällä 2012 esiintyi kausihuoneen kurkun versoissa pahkahometta kaikilla tutkimuspaikkakunnilla. Avomaakasvustot säästyivät pahkahomeelta. Vuonna 2013 riesana Sotkamossa ja Rovaniemellä olivat vihannespunkit. Ruukissa vihannespunkkia ei esiintynyt. Vihannespunkin torjuntaan käytettiin ansaripetopunkkia ja Carbon Kick Booster torjunta-ainetta. Torjunta yrityksistä huolimatta runsaana esiintyneet vihannespunkit vaikuttivat alentavasti erityisesti kausihuonekurkun sadon tuottoon ja satokauden pituuteen Sotkamossa ja Rovaniemellä.

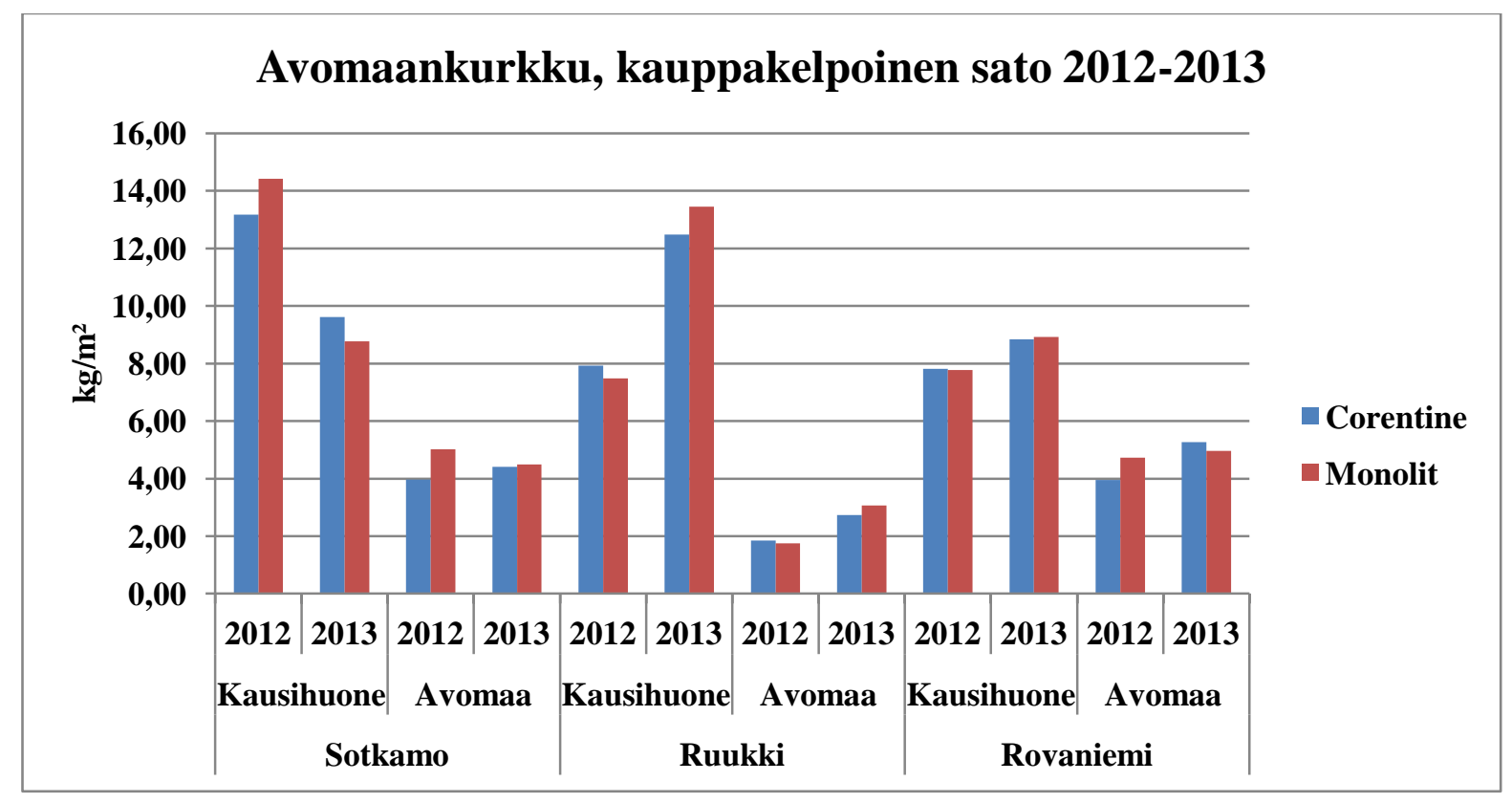

Kuva 1. Kahden avomaakurkkulajikkeen kauppakelpoinen sato $\left(\mathrm{kg} / \mathrm{m}^{2}\right)$ kausihuoneesta ja avomaalta MTT:n kolmella eri tutkimuspaikkakunnalla kasvukausina 2012 ja 2013. 


\section{Johtopäätökset}

Kausihuonekasvatus aikaisti avomaankurkunsatoa avomaahan verrattuna kaikilla tutkimuspaikkakunnilla, mutta Rovaniemellä aikaistava vaikutus oli suurin. Sadon aikaistumiseen avomaahan verrattuna vaikuttaa mahdollisuus aikaisempaan istutukseen ja taimien nopeampi kasvu. Kausihuone voi sääolosuhteiltaan huonona kesänä kohottaa satotasoja moninkertaisesti avomaahan verrattuna. Myös kasvuolosuhteiltaan suotuisampana kesänä kausihuoneesta saadaan suurempi sato kuin avomaalta. Kuitenkin olosuhteiltaan suotuisina kesinä kausihuoneen satoa aikaistava ja lisäävä vaikutus on pienempi kuin sääolosuhteiltaan huonompina kesinä.

Viileänä kesänä sadonlaatu voi kausihuoneessa olla parempi kuin lämpimänä kesänä. Lämpimänä kesänä avomaankurkun kausihuonetuotannossa on varauduttava erilaisiin tuholais- ja tautiongelmiin kuin viileänä ja sateisena kesänä. Kosteana kesänä kausihuoneessa oli ongelmana liikakosteus ja sen myötä pahkahome. Kuivana ja lämpimänä kesänä kausihuoneessa esiintyi ongelmaksi asti vihannespunkki. Molempien esiintymiseen ja leviämiseen olisi luultavasti voitu vaikuttaa kausihuoneen paremmalla tuuletuksella. Kausihuoneen tuuletus osoittautui tärkeäksi kesän sääolosuhteista huolimatta. Kausihuoneviljelyssä onkin tärkeää huolehtia tuuletuksesta kesän sääolosuhteiden mukaisesti.

Kausihuoneeseen päästään istuttamaan taimia aikaisemmin keväällä kuin avomaalle hallariskistä huolimatta. Avomaakasvatukseen verrattuna kausihuone vähentää ja helpottaa hallantorjuntaa keväällä. 